EESTI NSV TEADUSTE AKADEEMIA TOIMETISED 1955. IV kd,, nr. 1 ИЗВЕСТИЯ АКАДЕМИИ НАУК ЭСТОНСКОИ ССР 1955. Том IV, № 1

\title{
HALLPÄHKLIPUU (Juglans cinerea L.) KASVATAMISEST EESTI NSV-s
}

\section{O. HENNO}

Eesti NSV metsade tootlikkuse suurendamise eesmärgil on metsakasvatuse praktikasse hakatud üha rohkem juurutama uute kiirekasvuliste ja tehniliselt väärtuslike puuliikide sissetoomist meie puistute koosseisu.

On vaja välja selgitada meie oludele sobivaid uusi väärtuslikke puuliike, mida võiks meil kasvatada ning mida tuleks kasutada viljakatel kasvukohtadel esinevate vähemväärtuslike lehtpuunoorendike liigilise koosseisu rekonstrueerimisel. Selleks on vaja teha metsakasvatuslikke järeldusi seni meil kasvavatest eksootidest ja rajada uusi metsakultuure uute liikide kasvuomaduste, sobivate kasvukohatingimuste ning tehniliste omaduste selgitamiseks.

Uheks puuliigiks, mida sobiva kasvukoha valikul võiks kasvatada Eesti NSV metsakultuurides, on pähklipuulised (perekonna Juglans liigid). Pähklipuulistest on Eesti NSV kasvukohatingimustele sobivamateks osutunud peamiselt kaks liiki: $\mathrm{h}$ a $11 \mathrm{p}$ äh kli pu u (Juglans cinerea L.) ja mandžuuria pähkli puu (J. mandschurica Maxim.)

\section{Kasvukoht}

Seni on meil pähklipuid kasvatatud peamiselt dekoratiivpuudena parkides, sest vabalt kasvades omavad need suuri, paaritusulgsete liitlehtedega, laiuvaid võrasid.

Et pähklipuupuit on väga dekoratiivne ja tehniliselt väärtuslik eriti mööblipuiduna, tuleks selle väärislehtpuu sissetoomisele meie puistute koosseisu omistada senisest suuremat tähelepanu.

Teatavaid kogemusi pähklipuuliste kasvatamise võimaluste kohta Eesti NSV tingimustes võimaldab saada ainulaadne hallpähklipuu metsanduslik kultuur Kurista metsamajandis Kuremaa Metsakooli juures oleva Kaarepere metskonna Luua vahtkonna kvartalitel nr. 137 ja nr. 139 kogusuurusega 0,8 ha. Mõlemad nimetatud kultuurid kasvavad teineteise naabruses olevatel kvartalitel, mida eraldab ainult kvartalitevaheline siht, ja moodustavad seega enam-vähem ühtse terviku.

Nimetatud hallpähklipuu-kultuur on seda tähelepanuväärivam, et hallpähklipuud esineb seni NSV Liidu metsakultuurides üldiselt vähe ning see kultuur on autorile kättesaadava kirjanduse andmeil üks suuremaid NSV Liidus.

Hallpähklipuu kasvab oma kodumaal (Põhja-Ameerikas) jõgede ja järvede äärsetes saluiseloomulistes segametsades, saavutades kuni 30-meet- 
rise kõrguse ning 100-120 cm suuruse läbimõõdu. Eelistab värskeid kuni niiskeid liikuva põhjaveega saviliiv- ja liivsavipinnaseid. NSV Liidu kirjanduse andmeil on ta võrdlemisi tundlik kuivuse suhtes.

Luua vahtkonna hallpähklipuu-kultuurid on rajatud karbonaatsetele sügavapõhjalistele saviliiv- kuni liivsavipinnastele oru läänepoolsele nõlvakule. Pinnas on niiskuseastmelt värske kuni niiske, põhjavesi liikuv. 1953. aasta sügisel oli põhjavesi ca $50-80 \mathrm{~cm}$ sügavusel. Boniteet $\mathrm{I}$.

Pinnase iseloomu kindlakstegemiseks kaevati 1953. a. sügisel 2 mullaprofiil-auku:

\section{1. a u k kvartalil nr. 137}

Ao $\quad 0-2 \mathrm{~cm}$ pooleldi lagunenud lehtedest metsakōdu,

$\mathrm{A}_{1} \quad 3-40$, mustjaspruun, juurtega läbi põimitud huumusmuld,

$\mathrm{A}_{2} / \mathrm{B} \quad 41-70$," beežikas, struktuurne, värske saviliiv,

B üle 70 ," hallikaspruun struktuurne (kruusakas) liivsavi, hulgaliselt lubjakivitükikesi (diameeter $1-3 \mathrm{~cm}$ ).

\section{2. auk kvartalil nr. 139}

Ao $\quad 0-2 \mathrm{~cm}$ pooleldi lagunenud lehtedest metsakõdu,

$A_{1} \quad 3-25$, mustjaspruun, juurtega läbị põimitud huumusmuld,

$\mathrm{A}_{2} / \mathrm{B} \quad 26-60$, beežikas; struktuurne saviliiv,

B üle 60 , hallikaspruun, kruusakas liivsavi, hulgaliselt lubjakivitükikesi (diameeter ca $1 \mathrm{~cm})$.

Mullastiku tingimusilt on kultuuri asukoht seega õigesti valitud, kuid ekspositsioonilt ebaõnnestunud, sest kultuurid külgnevad põhjast ja idast heinamaaga, mistõttu nad on mõjustatavad põhja- ja idatuulte poolt.

Kultuurid on rajatud (endise metsavahi A. P u h t z it i andmeil, kes isiklikult võttis osa nimetatud kultuuride rajamisest) 1911. aastal puhaskultuuridena seaduga $2,4 \times 2,4 \mathrm{~m}(8 \times 8$ jalga, ca 1725 istutuskohta ha kohta). Kultiveerimismaterjalidena kasutati mitmeaastasi seemikuid, mis olid ette valmistatud taimeaias. Seeme oli tellitud Kanadast ja Jaapanist. Jaapanist tellitud seemnest põlvneb tõenäoliselt üks Siiboldi pähklipuu Kuremaa Metsakooli pargis, mis kannab vilja ega ole kannatanud külma läbi (kõrgus $18 \mathrm{~m}$, diameeter $1,3 \mathrm{~m}$ kõrgusel $-\mathrm{d}_{1,3}=65 \mathrm{~cm}$ ). Teisi Siiboldi pähklipuu eksemplare ei esine pargis ega ka metsakultuurides.

Hallpähklipuu-kultuuri vanus on ca 45 aastat.

\section{Puistu kasvuarenguline iseloomustus}

Puistu takseerimistunnuste iseloomustamiseks rajati proovitükke: 1939. aastal kvartalil nr. 139 ja 1953. aastal kvartalitel nr. 137 ja nr. 139.

1939. aasta sügisel rajatud 0,08 ha $(20 \times 40 \mathrm{~m})$ suuruselt proovitükilt saadi ühe hektari kohta järgmised andmed:

Tabel 1

\begin{tabular}{|c|c|c|c|c|c|c|c|}
\hline \multirow{2}{*}{ Puuliik } & \multicolumn{3}{|c|}{ Puude keskmine } & \multirow{2}{*}{$\begin{array}{c}\text { Puude } \\
\text { arv }\end{array}$} & \multirow{2}{*}{$\begin{array}{l}\text { Lõike- } \\
\text { pind } \\
\mathrm{m}^{2}\end{array}$} & \multirow{2}{*}{$\begin{array}{l}\text { Taga- } \\
\text { vara } \\
\text { tm }\end{array}$} & \multirow{2}{*}{$\begin{array}{l}\text { Keskmine } \\
\text { juurde- } \\
\text { kasv tm }\end{array}$} \\
\hline & vanus a. & $\mathrm{d}_{1,3} \mathrm{~cm}$ & $\begin{array}{c}\text { kōrgus } \\
\mathrm{m}\end{array}$ & & & & \\
\hline $\begin{array}{l}\text { Hallpăhklipuu (J. cine- } \\
\text { rea L.) } \\
\text { Valgelepp (Alnus in- } \\
\text { cana) }\end{array}$ & 28 & $\begin{array}{l}13,1 \\
11,2\end{array}$ & 12 & $\begin{array}{r}1688 \\
75\end{array}$ & $\begin{array}{r}22,97 \\
0,75\end{array}$ & $\begin{array}{r}123,4 \\
3,6\end{array}$ & 4,4 \\
\hline Kokku & & 13,1 & 12 & 1763 & 23,72 & 127,0 & \\
\hline
\end{tabular}


Puud asetsesid sel ajal (1939. a.) veel korrapärastes, põhjast lõunasse suunduvates ridades. Võrad olid laiad ja liitunud. Et kultiveerimissead oli võrdlemisi suur ning kultuurid rajatud puhaspuistutena (ilma ajepuudeta), siis oli laasunud tüveosa võrdlemisi madal (ca $2 \mathrm{~m}$ ) ning sirge tüveosa ei ulatunud palju üle 4 meetri.

Uldiselt jättis kultuur täiesti elujõulise puistu mulje. Proovitükil olevad puud kuulusid kõik ülarindesse, kuna teise rinde ja alla $8 \mathrm{~cm}$ jämedusega puid ei esinenud.

Alusmetsana esinesid harilik saar (Fraxinus excelsior), toomingas (Padus racemosa) ja kuslapuu (Lonicera xylosteum).

Alustaimestik: vaarikas (Rubus idaeus), harilik naat (Aegopodium podagraria), angervaks (Filipendula ulmaria), suur aruhein (Festuca gigantea) ning sammaldest metsakäharik (Rhytidiadelphus triquetrus) ja lainjas tähtsammal (Mnium undulatum).

Proovitüki andmeist ilmneb, et hallpähklipuu kasvuarenguline kulg noores eas on antud kasvukohal toimunud täiesti rahuldavalt, ehkki tüve üldine vorm jättis soovida, mida tuleb panna ebaõige kultiveerimisviisi arvele. Eriti väärib aga märkimist, et hallpähklipuu, olles Eesti NSV-s oma kasvuareaali pōhjapiiril, talus kuni 1939. aastani tavalisi talvekülmi, kuigi kultuur oli asukoha suhtes rajatud väga ebasoodsatesse tingimustesse, nagu eespool kirjeldatud.

Saatuslikuks sai aga kultuurile 1940. aasta erakordselt külm, väga suurte temperatuurikõikumistega talv. Nii langes Jõgeval, ca $16 \mathrm{~km} \mathrm{kau-}$ gusel hallpähklipuu-kultuuri asukohast, temperatuur 15 . jaanuaril 0 kraadilt järsult kuni - 36 kraadini ja püsis madalana nädalapäevad (madalaim temperatuur $-44^{\circ} \mathrm{C}$ oli 17 . jaanuaril). Erakordselt külmi ilmu ja suuri temperatuurikõikumisi esines ka veebruaris. Selle tagajärjel oli külmakahjustus niivõrd suur, et 1940. aasta suvel olid puud täiesti raagus: ainult üksikutel leidus mõni roheline leht. Väliselt paistis, et kultuur on täiesti hukkunud, kuid puude juured olid välja ajanud rikkalikult kännuvõrseid. 1940. aasta talve külmakahjustuse all kannatasid ka meie pōlised puuliigid, näiteks sanglepp (Alnus glutinosa) ja harilik saar (Fraxinus excelsior).

Siinjuures on aga huvitav märkida, et kultuurist ca $0,5 \mathrm{~km}$ kaugusel olevas Metsakooli pargis jäid nii vanemad hallpähklipuu eksemplarid kui ka Siiboldi pähklipuu külmast täiesti kahjustamata. Nimetatud eksemplarid on praegu täiesti terved ja kannavad rikkalikult vilja. Nendest Siiboldi pähklipuu on praegu $18 \mathrm{~m}$ kõrge ning tema diameeter $1,3 \mathrm{~m}$ kõrgusel on $65 \mathrm{~cm}$. Suurim pargis kasvav pähklipuu on $21 \mathrm{~m}$ kõrge ja $66 \mathrm{~cm}$ suuruse diameetriga. Teiste pargis kasvavate hallpähklipuude diameeter $d_{1,3}$ on $40-60 \mathrm{~cm}$, kõrgus $17-20 \mathrm{~m}$.

Seda nähtust saab seletada ainult ekspositsiooniliste erinevustega. Pargis kasvavad eksemplarid olid teiste puude vahel, enam-vähem tasasel ja kõrgemal kohal, kuna eespoolkirjeldatud kultuur oli täielikult avatud külmadele idatuultele ja asetses madalamas kohas, kuhu moodustus nn. külmalohk.

1940. aasta külmakahjustust aitas suurendada veel 1939. aasta erakordselt kuiv suvi, mistõttu sügisel pinnas sisaldas vähe niiskust ning suur osa külmakahjustusi võis tekkida füsioloogilise kuivuse tagajärjel. Seda väidet tõestab asjaolu, et osa puid, mis asetses oru pōhjas niiskel pinnasel, jäi külma poolt kahjustamata.

Ehkki esimesel suvel pärast külma talve näis, et kultuur on täiesti hukkunud, osutus puude väljalangemine tegelikult üsna väikeseks. Külma tagajärjel tekkis tüvedele ühepoolne kuivkülgsus, mis ribana ulatus $1-2 \mathrm{~m}$ kõrgusele. Tugevamalt vigastatud puud raiuti maha, kuid nende kännuvõr- 
setest arenesid uued, noored puud, milliseid hooldusraiete puhul jäeti kasvama tavaliselt kännu kohta üks, harvemal juhul kaks. Nõrgemalt vigastatud puudel toimub käesoleval ajal haavandite intensiivne kinnikasvamine. Külma tagajärjel tekkinud haavandid on tüvedel peaaegu eranditult kirdeida pool, mis veelkordselt tõendab kõnesolevate kultuuride ekspositsioonilist sobimatust.

Hallpähklipuu kultuuride praegust seisundit iseloomustavad proovitükkide andmed. Proovitükid rajati autori poolt 1953. aasta sügisel.

Esimene proovitükk rajati kvartalil nr. 137 asetsevasse kultuuri, kust hooldusraietega on kõrvaldatud ainult väga tugevasti külma läbi kahjustatud puud, ning teine kvartalile nr. 139, kust hooldusraietega on kõrvaldatud kõik vigastatud puud.

1. Proovitükk kvartalil nr. 137 , suurusega 0,10 ha $(40 \times 25 \mathrm{~m})$. Puistu keskmine vanus 45 aastat. Koosseis 8 Päh $1 \mathrm{Sa} 1 \mathrm{Lv}$, täius 0,7 , boniteet I. Järelkasv - saar (Fraxinus excelsior); alusmets toomingas (Padus racemosa), sarapuu (Corylus avellana); alustaimestik angervaks (Filipendula ulmaria), sinilill (Hepatica nobilis), võsaülane (Anemone nemorosa), metspipar (Asarum europaeum), kortsleht (Alchemilla vulgaris). Reljeef - oru läänekallak, pinnas kirjeldatud eespool.

Tabelis 2 esitatakse tähtsamad takseerimiselemendid arvestusega ühe hektari kohta.

Tabel 2

\begin{tabular}{|c|c|c|c|c|c|}
\hline \multirow[b]{2}{*}{ Puuliik } & \multicolumn{2}{|c|}{ Puude keskmine } & \multirow{2}{*}{ Puude arv } & \multirow{2}{*}{$\begin{array}{l}\text { Lõikepind } \\
\mathrm{m}^{2}\end{array}$} & \multirow{2}{*}{$\underset{\text { tm }}{\text { Tagavara }}$} \\
\hline & $\mathrm{d}_{1,3} \mathrm{~cm}$ & $\begin{array}{c}\text { kõrgus } \\
\mathrm{m}\end{array}$ & & & \\
\hline $\begin{array}{l}\text { Hallpăhklipuu (seemnest } \\
\text { kasvanud, külmakahjus- } \\
\text { tuse tile elanud) }\end{array}$ & $18,5^{\prime}$ & 16 & 310 & 8,3660 & 77,0 \\
\hline $\begin{array}{l}\text { Hallpăhklipuu (kănnuvõr- } \\
\text { setest kasvanud) }\end{array}$ & 5,2 & 6 & 270 & 0,5660 & 5,1 \\
\hline Saar (Fraxinus excelsior) & 21,6 & 21 & 30 & 1,1010 & 10,5 \\
\hline Valgelepp (Alnus incana) & 20,3 & 18 & 30 & 0,9740 & 8,1 \\
\hline Kokku & & & 640 & 11,0070 & 100,7 \\
\hline
\end{tabular}

Toodust selgub, et puistu praegune tagavara on võrdlemisi väike, sest käesoleva ajani säilitatud hallpähklipuude arvust on ca $46 \%$ kännuvõrseist kasvanud puukesed.

Kui käesoleva ajani oleksid säilinud kõik seemnest kasvanud (esialgse kultuuri) puud, siis oleks puistu praegune tagavara ca $180 \mathrm{tm}$ hektari kohta.

Tegelikult on seemnest kasvanud pähklipuudest, mis on käesoleva ajani säilitatud, ca $80 \%$ puid külmakahjustustega; nende hulgast võiks tugevamalt kahjustatud puid veelgi likvideerida.

2. Proovitükk kvartalil nr. 139 , suurusega 0,18 ha $(35 \times 51,5 \mathrm{~m})$. Puistu, milles hallpähklipuu esineb kännuvõrseist arenenud noormetsana, on keskmiselt 10 aastat vana. Koosseis $4 \mathrm{Päh} 3 \mathrm{Sa} 2 \mathrm{Ks}$ $1 \mathrm{Lv}+\mathrm{Ku}$. Järelkasv - saar (Fraxinus excelsior) ja kuusk (Picea excel$s a)$; alusmets - toomingas (Padus racemosa), sarapuu (Corylus avellana), kuslapuu (Lonicera xylosteum); alustaimestik - angervaks (Filipendula ulmaria), võsaülane (Anemone nemorosa), metstulikas (Ranunculus cassubicus), metspipar (Asarum europaeum), metsmaasikas (Fra- 
garia vesca), sinilill (Hepatica nobilis). Reljeef - oru läänekallak, eelmisest üldiselt kõrgem. Pinnas on kirjeldatud eespool.

Puistu kannatas külmakahjustuse läbi tunduvalt rohkem, mistõttu sanitaar-hooldusraietega on kõrvaldatud peaaegu kõik kahjustatud puud. Eelviimane hooldusraie teostati 1950. aastal, millal likvideeriti praktiliselt viimased kahjustatud puud. Varem raiutud puude kännuvõrseist jäeti kännu kohta alles $1-2$, harvem 3 võrset.

1953. aastal teostati järjekordne hooldusraie - kõrvaldati üksikuid suuremaid kaski, leppi jt., mis takistasid kännuvõrseist kasvanud puukešte normaalset arenemist. Kännuvõrseist arenenud puukeste individuaalset hooldamist teostati madalamate okste laasimisega.

Keskmised takseerimisandmed hektari kohta pärast 1953. aasta hooldusraiet on toodud tabelis 3 .

Tabel 3

\begin{tabular}{|c|c|c|c|c|c|}
\hline \multirow{2}{*}{ Puuliik } & \multicolumn{2}{|c|}{ Puude keskmine } & \multirow{2}{*}{$\begin{array}{l}\text { Puude } \\
\text { arv }\end{array}$} & \multirow{2}{*}{$\begin{array}{l}\text { Lõikepind } \\
\mathrm{m}^{2}\end{array}$} & \multirow{2}{*}{$\underset{\mathrm{tm}}{\text { Tagavara }}$} \\
\hline & $\mathrm{d}_{1,3} \mathrm{~cm}$ & $\underset{\mathrm{m}}{\text { kõrgus }}$ & & & \\
\hline Hallpahklipuu (seemnest) & 21,0 & 15,0 & 89 & 3,0828 & 29,7 \\
\hline $\begin{array}{l}\text { Hallpăhklipuu (kănnuvõr- } \\
\text { seist) }\end{array}$ & 8,6 & 9,0 & 461 & 2,6611 & 13,8 \\
\hline $\begin{array}{l}\text { Saar (Fraxinus excel- } \\
\text { sior) }\end{array}$ & 17,7 & 19,0 & 100 & 2,4683 & 27,4 \\
\hline $\begin{array}{l}\text { Tamm (Quercus pedun- } \\
\text { culata) }\end{array}$ & 25,0 & 20,0 & 6 & 0,2728 & 2,7 \\
\hline Kask (Betula verrucosa) & 25,6 & 23,0 & 39 & 2,0072 & 22,4 \\
\hline Kuusk (Picea excelsa) & 8,7 & 9,0 & 72 & 0,4267 & 2,1 \\
\hline $\begin{array}{l}\text { Valgelepp } \\
\text { cana })\end{array}$ & 13,9 & 12,0 & 100 & 1,5200 & 12,4 \\
\hline Kokku & & & 867 & 12,4389 & 110,5 \\
\hline
\end{tabular}

Toodud andmeist selgub, et pärast hooldusraiet moodustasid pähklipuud üldisest puude arvust puistus $63 \%$. Oldine tagavara oli $110,5 \mathrm{tm}$, sellest pähklipuud 43,5 tm ehk $39 \%$.

1953. aastal kõrvaldati hooldusraietega hektari kohta kaski $23,3 \mathrm{tm}$, valgeleppi $20,7 \mathrm{tm}$ ja pähklipuid $4,5 \mathrm{tm}$, kokku $48,5 \mathrm{tm}$ ehk $30,5 \%$ esialgsest tagavarast, mis oli $159 \mathrm{tm}$.

Silmapaistev on kännuvõrseist kasvanud pähklipuude intensiivne kasv ca 10 aasta vanuste puude keskmine kõrgus on $9 \mathrm{~m}$ ja keskmine diameeter $8,6 \mathrm{~cm}$.

Hallpähklipuu puistu kasvukäigu iseloomustamiseks teostati puu analüüs keskmise läbimõõdu liitvalemi järgi $1 \mathrm{~m}$ sektsioonidega. Analüüsipuu raiuti kvartalil nr. 137 olevalt proovitükilt.

Analüüsipuu üldised andmed olid: vanus 45 aastat, kõrgus $17,3 \mathrm{~m}$, $\mathrm{d}_{1,3}=23,0 \mathrm{~cm}$, tüve maht $0,2975 \mathrm{tm}$, koore maht $0,0432 \mathrm{tm}$ ehk $14,5 \%$ tüve mahust.

Andmeist nähtub, et kõrguse jooksev juurdekasv kulmineeris ca 20 . aastal, olles $0,50 \mathrm{~m}$, kusjuures viimasel vaatlusperioodil (40.-45. a.) moodustas see $0,30 \mathrm{~m}$, s. t. oli kulminatsiooniga vōrreldes tunduvalt vähenenud. Diameetri jooksev juurdekasv $1,3 \mathrm{~m}$ kõrgusel kulmineeris 10.-15. aasta vahel $0,66 \mathrm{~cm}$ suuruses, kusjuures pärast kulminatsiooni on dia- 
Analüüsipuu takseerimiselementide juurdekasvud

Tabel 4

\begin{tabular}{|c|c|c|c|c|c|c|c|c|c|}
\hline \multirow{2}{*}{$\begin{array}{c}\text { Vanus } \\
\text { a. }\end{array}$} & \multirow{2}{*}{$\begin{array}{c}\text { Kõrgus } \\
\text { m }\end{array}$} & \multicolumn{2}{|c|}{$\begin{array}{c}\text { Kõrguse juurde- } \\
\text { kasv m }\end{array}$} & \multirow{2}{*}{$\begin{array}{c}\text { Diameeter } \\
1,3 \mathrm{~m} \\
\text { kõrgusel } \\
\mathrm{cm}\end{array}$} & \multicolumn{2}{|c|}{$\begin{array}{c}\mathrm{d}_{1,3} \text { juurdekasv } \\
\mathrm{cm}\end{array}$} & \multirow{2}{*}{$\underset{\mathrm{tm}}{\text { Maht }}$} & \multicolumn{2}{|c|}{$\begin{array}{c}\text { Mahu juurde- } \\
\text { kasv tm }\end{array}$} \\
\hline & & $\begin{array}{l}\text { kesk- } \\
\text { mine }\end{array}$ & jooksev & & $\begin{array}{l}\text { kesk- } \\
\text { mine }\end{array}$ & jooksev & & $\begin{array}{l}\text { kesk- } \\
\text { mine }\end{array}$ & jooksev \\
\hline $\begin{array}{r}5 \\
10 \\
15 \\
20 \\
25 \\
30 \\
35 \\
40 \\
45\end{array}$ & $\begin{array}{r}1,0 \\
2,9 \\
5,0 \\
7,5 \\
10,0 \\
12,2 \\
14,2 \\
15,8 \\
17,3\end{array}$ & $\begin{array}{l}0,20 \\
0,29 \\
0,33 \\
0,38 \\
0,40 \\
0,41 \\
0,41 \\
0,40 \\
0,38\end{array}$ & $\begin{array}{l}0,20 \\
0,38 \\
0,42 \\
0,50 \\
0,50 \\
0,44 \\
0,40 \\
0,32 \\
0,30\end{array}$ & $\begin{array}{r}0 \\
3,0 \\
6,3 \\
9,0 \\
11,5 \\
14,0 \\
16,0 \\
18,1 \\
20,6\end{array}$ & $\begin{array}{l}0, \overline{30} \\
0,42 \\
0,45 \\
0,46 \\
0,47 \\
0,46 \\
0,45 \\
0,46\end{array}$ & $\begin{array}{l}0,30 \\
0,66 \\
0,54 \\
0,50 \\
0,50 \\
0,40 \\
0,42 \\
0,50\end{array}$ & $\begin{array}{c}-\overline{0} 06 \\
0,00065 \\
0,00526 \\
0,02286 \\
0,0694 \\
0,1123 \\
0,1787 \\
0,2543\end{array}$ & $\begin{array}{c}0,0001 \\
0,0004 \\
0,0011 \\
0,0015 \\
0,0023 \\
0,0030 \\
0,0045 \\
0,0056\end{array}$ & $\begin{array}{l}0,0001 \\
0,0010 \\
0,0034 \\
0,0032 \\
0,0062 \\
0,0086 \\
0,0133 \\
0,0151\end{array}$ \\
\hline
\end{tabular}

meetri juurdekasv kulgenud üldiselt jõuliselt, näidates viimasel vaatlusperioodil (40.-45. a.) uut tõusu.

Eesti NSV kasvutingimustes, asudes oma kasvutsooni põhjapiiril, jääb hallpähklipuu körguse poolest teisejärguliseks puuks (kõrguse maksimum ca $20 \mathrm{~m}$ ). Kõrguse suhteline väljakasv toimub üsna noores eas. Nii näiteks oli Kuremaa Metsakooli juures asetseva 45-aastase kultuuri keskmine kõrgus $16,0 \mathrm{~m}$, analüüsipuu kõrgus aga $17,3 \mathrm{~m}$.

Pähklipuude üldist suurt diameetrit 1,3 m kõrgusel (vanemad puud kooli pargis) võib seletada diameetri intensiivse, kauapüsiva kasvuga noores eas.

Neid kasvuomadusi tuleb ära kasutada puistute majandamisel, arvestades ühtlasi asjaolu, et hallpähklipuu füüsilist iga ei peeta kõrgeks (ca 100 aastat).

\section{Kultiveerimine}

Pähklipuude kultiveerimisel tuleb lähtuda nimetatud puuliigile omaseist metsakasvatuslikest omadusist ja seemnete eriomadusist. Hallpähklipuu vili on võrdlemisi suur ( $4-5 \mathrm{~cm}$ pikk) ja tugevasti puitunud kattega. Viljakandvus on üldiselt rohke ning sage, normaalsetel aastatel peaaegu iga-aastane. Eesti NSV oludes võivad viljakandvust oluliselt mõjutada hiliskülmad, hävitades mõnel aastal vilja täielikult. Nii näiteks 1953. aastal hiliskülma tagajärjel puudus viljakandvus täiesti. Kuremaa Metsakooli andmetel oli hallpähklipuu viljakandvus rikkalik 1950. ja 1952. aastal. 1952. aastal kandsid rikkalikumalt vilja valguse käes rühmadena kasvavad puud; ka seemne kvaliteet oli valguse käes rühmadena kasvanud puudelt kogutud viljadel parem kui liitunud puistust kogutud viljadel.

Hallpähklipuu viljakandvus algab üldiselt vara. Kuremaa Metsakooli juures olevate kultuuride viljakandmise alguse kohta puuduvad andmed. Varasematest andmetest on teada, et 1939. aastal oli rikkalik saak. Puistu vanus oli siis 28 aastat. Tollal puud kandsid rohkesti pähkleid, mis Luua metsavahi taimeaias toimunud külvi tulemuste järgi otsustades olid hea idanevusega. Samal ajal võis ka leida üksikuid seemnest tärganud taimi kultuuri hõredamatel kohtadel. Oldiselt võib pähklipuude viljakandvuse alguseks pidada $15-20$-aastast vanust.

Et Eesti NSV tingimustes osutub parimaks hallpähklipuude kultiveerimise viisiks kas seemikute või puukoolis kasvatatud taimede istutamine, siis tuleb seemnekoguste piiratuse tõttu erilist tähelepanu omistada viljade kogumisele, säilitamisele ja külviks ettevalmistamisele. 
Uute liikide introdutseerimisel tuleb tähelepanu pöörata ka nende talvekindlusele, arenemisele ja üldisele vormile. Selektsiooni tuleb selleks teostada juba viljade kogumisel ja ka taimeaias seemikute hulgas.

Teatud liigi kohanemise kiirendamiseks on oluline viljade kogumist teostada mitte üksikult, vaid gruppides kasvavatelt puudelt, millede puhul on kindlustatud omavaheline risttolmlemine.

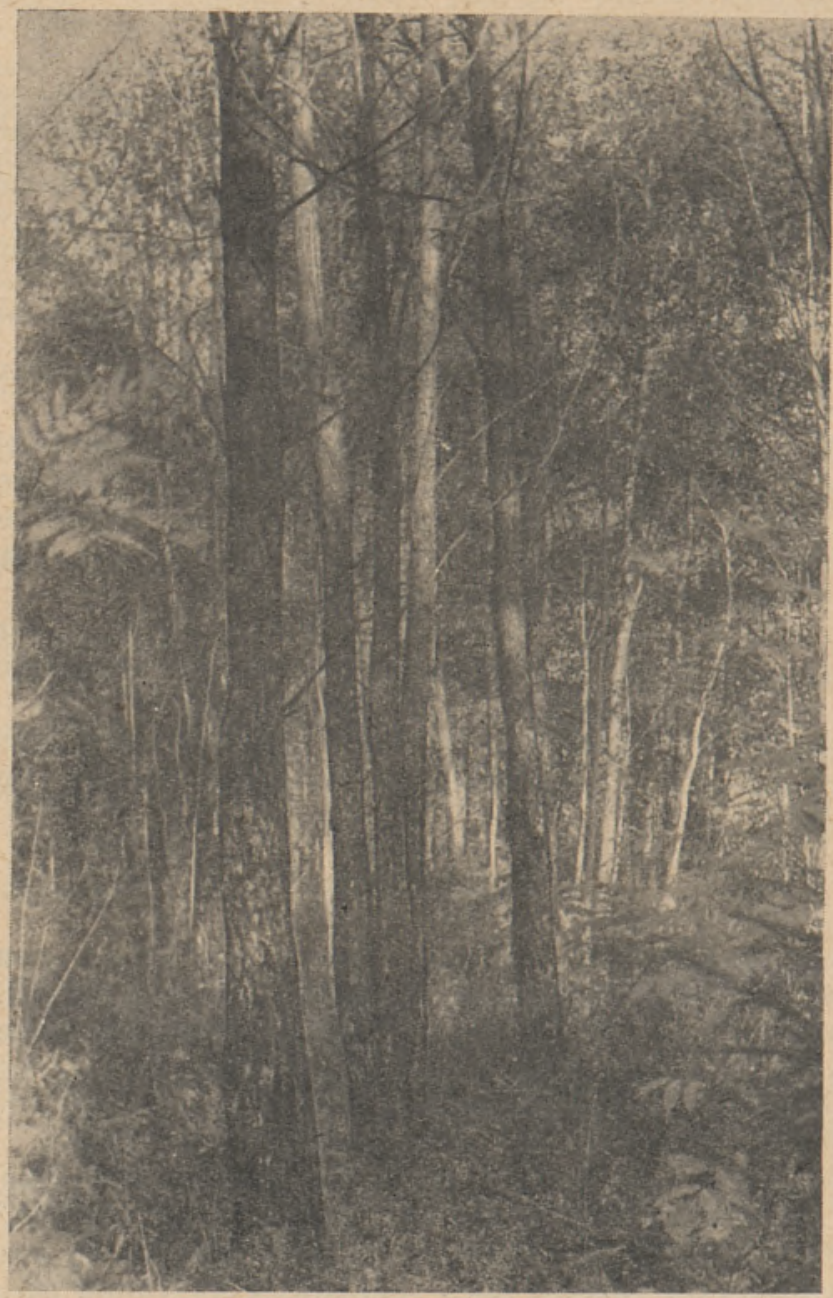

Joon. 1. Seemnest arenenud hallpähklipuu kultuur kvartalil nr. 137 (vanus 45 a.). Tüvede allosas näha külmakahjustuste haavandid.

Seemnete säilitamist ja külviks ettevalmistamist tuleb teostada stratifitseerimise teel. Kuremaa Metsakooli praktikas on stratifitseerimist ja säilitamist teostatud kahel viisil.

1. Keldris kastidesse paigutatult -3 kihti pähkleid vaheldumisi liiva vōi turvasmulla kihtidega; liivakihi paksus on 3-4 cm, kusjuures păhklikihis laotakse pähklid püsti üksteise kôrvale. Pealmine pähklikiht kaetakse samuti liiva- vỗi turvasmulla kihiga ning seemnekastide sisu niisutatakse üks kord kuus hästi läbi.

2. Väljas suurtes lavakastides (samuti kolm kihti pähkleid ja neli kihti liiva või turvasmulda). Lavakastid kaetakse pealt kinni puudelt langenud lehtedega, kus- 
juures kate peab olema nii paks, et talvel seemned ära ei külmuks, sest läbikülmunud seemned kaotavad idanemisvōime.

Istutusmaterjali saamiseks külvatakse stratifitseeritud pähklid mai keskpaiku taimeaeda külvipeenrale. Külvirennid tehakse 30-sentimeetriste vahedega ning pähklid laotakse külvirennidesse otstega kokku. Tõusmed ilmuvad üsna pika aja järele, keskmiselt 2-3 nädala jooksul. Idanevus on taimeaia looduslikes tingimusis olnud keskmiselt $60-70 \%$. Kui tahetakse saada koolitatud istutusmaterjali,' siis tuleb koolitus teostada üheaastaste seemikutega ning tingimata kevadel, sest Kuremaa Metsakooli praktikas ei ole sügisene koolitus andnud rahuldavaid tulemusi.

Metsakultuuride rajamisel tuleb erilist tähelepanu pöörata õige kasvukoha, ekspositsiooni ja kultuuritüübi valikule.

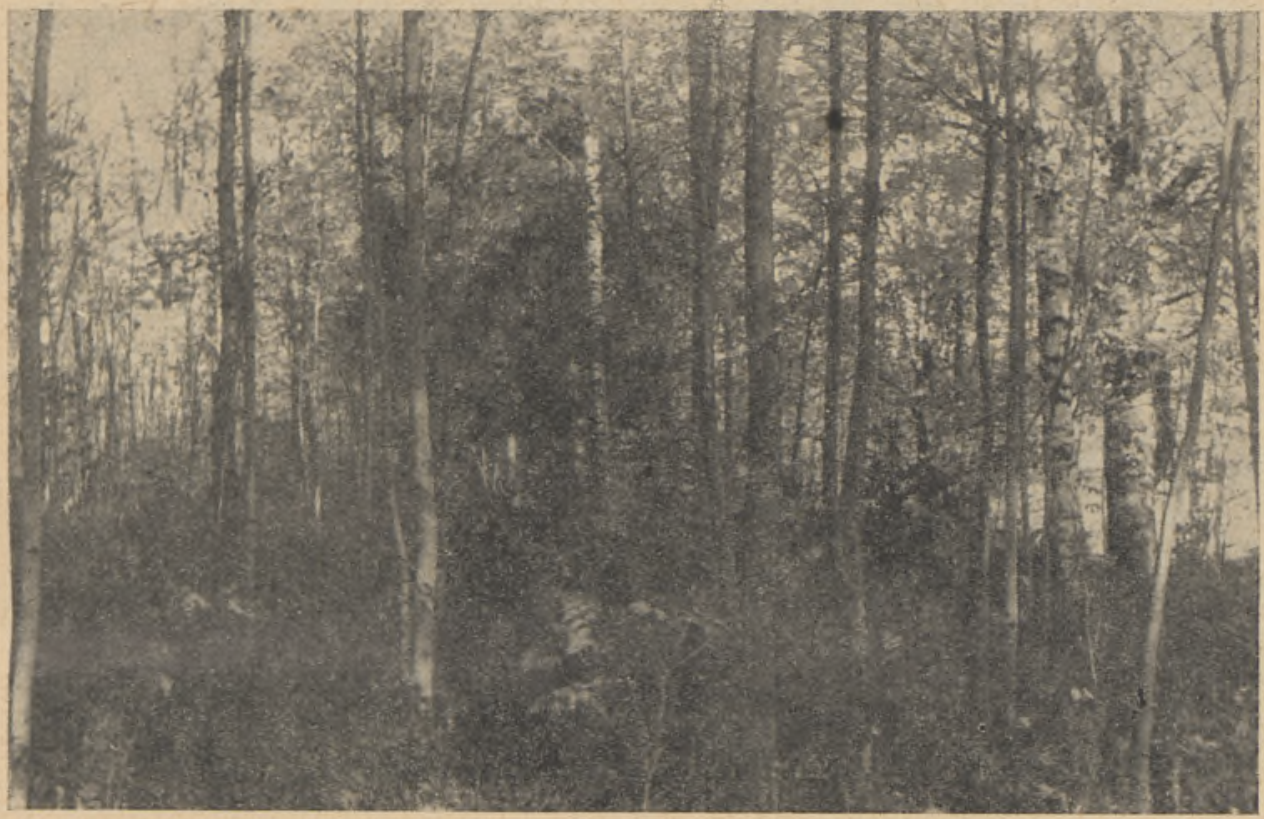

Joon. 2. Kännuvõrseist arenenud hallpähklipuu puistu kvartalil nr. 139 enne hooldamist (vanus 10 a.)

Kasvukohaks sobivad viljakad, sügavapõhjalised, niisked, kuid liikuva põhjaveega maad. Parimateks kasvukohtadeks on jõgede või kraavide äärsed salumetsatüübilised kallakud, mis on tuulte eest kaitstud ning sobivad ka teiste väärislehtpuude (tamm, vaher jt.) kasvatamiseks.

Kuigi hallpähklipuu on oma kodumaal pinnase suhtes vähem nõudlik, ei saa seda arvestada meie oludes, sest väljaspool oma loomulikku kasvuareaali nõuavad eksoodid üldiselt paremaid pinnaseid.

Hallpähklipuu kasvab oma kodumaal rühmaviisi koos teiste lehtpuuliikidega ja ei moodusta puhaspuistuid. Sellest tingimusest tuleks kultuuritüüpide valikul kinni pidada ka Eesti NSV oludes, sest olemasolcvad kultuurid tōendavad selgesti selle otstarbekust. Puhaskultuurides, kus kultuurisead ei ole küllalt tihe, moodustavad pähklipuud madala, laiuva võra, mille tagajärjel kannatab tüve üldine vorm (vt. joon. 1). Parema tüve moodustamiseks vajavad pähklipuud ajepuid, milleks nende noores eas sobivad põõsasliigid ja hiljem teised pähklipuude kasvukohale sobivad 
ning nendega enam-vähem võrdsete kasvuomadustega puuliigid, nagu tamm, vaher, jalakas, künnapuu, ameerika saar, pärn ja ajutiselt puistu noores eas ka valgelepp, haab, kask.

Kaaspuuliikide head mõju tüve vormi kujunemisele tõestab puude arenemine kvartalile nr. 139 rajatud proovitükil, mis on näha ka joonistelt 2. ja 3. Sellel proovitükil kasvasid kännuvõrseist arenenud puud koos teiste puuliikidega - kasega, valgelepaga, saarega, vahtraga (joon. 2), mis on soodustanud hea tüve vormi kujunemist (joon. 3).

Kultuuritüübi valikut lihtsustab asjaolu, et noores eas pähklipuud ei kannata kaaspuuliikide varjavuse all. Seevastu vanemas eas on pähklipuud küllaltki suure valgusenõudlikkusega, mistõttu neil peab olema või-

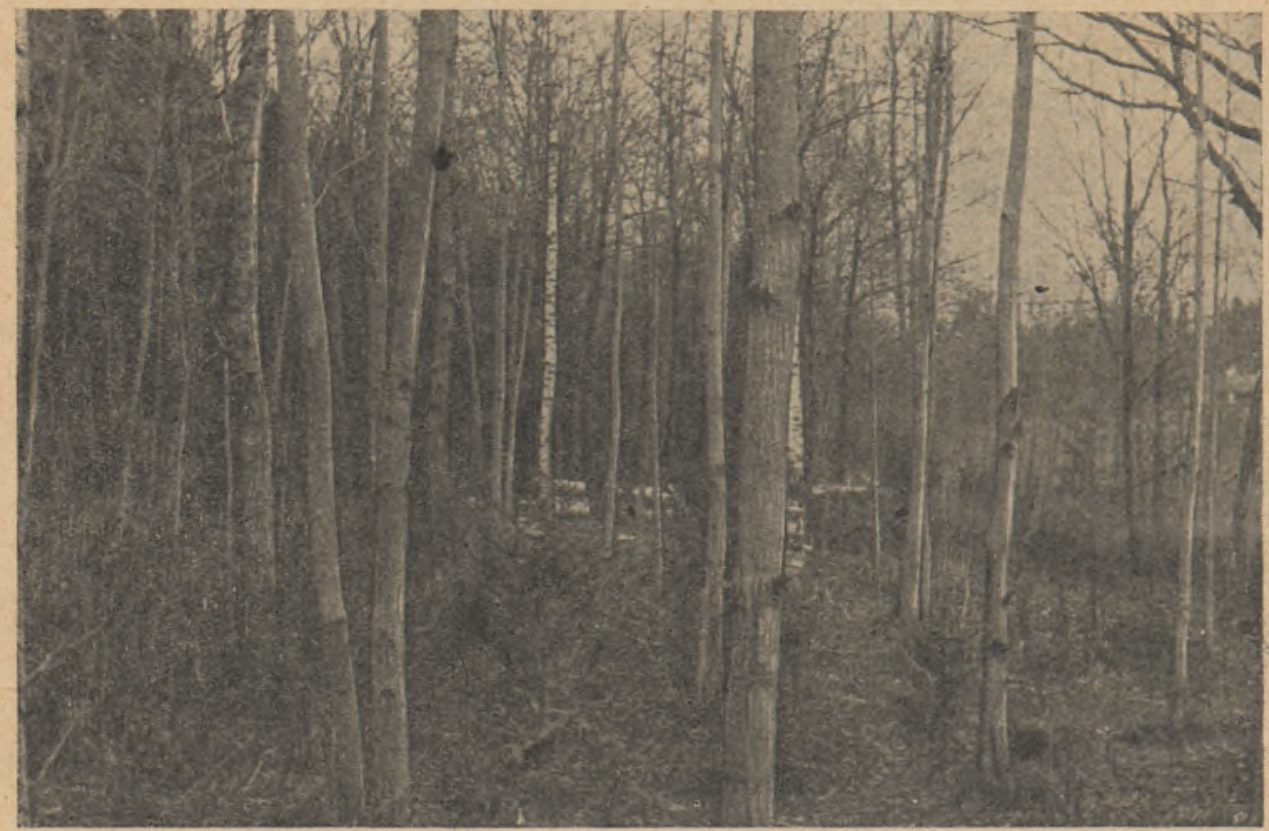

Joon. 3. Kännuvõrseist arenenud hallpähklipuu puistu kvartalil nr. 139 pärast hooldamist (vanus 10 a.)

malus moodustada omaette ülarinnet. Seetõttu hallpähklipuude kasvatamine koos meie tavalisemate metsapuuliikidega, nagu näiteks kask ja haab, võib kõne alla tulla ainult suuremate rühmadena, sest nende puude kõrgusekasv on pähklipuudega võrreldes viimastele soodsatel kasvukohtadel tunduvalt suurem. Kultuuritüübi valikul tuleb lähtuda ka istutusmaterjali kokkuhoiu põhimõttest, sest meie oludele kohandunud seemne ja istutusmaterjali saamine on raskendatud. Eesti NSV tingimustes pakuvad head seemnete saamise võimalust eespoolmainitud kultuurid ja puude rühmad Kuremaa Metsakooli juures, kust seemneaastail saab küllaldaselt pähkleid koguda.

Hallpähklipuu kujuneb Eesti NSV tingimustes väärtuslikuks puuliigiks vähemväärtuslike lehtpuunoorendike rekonstrueerimisel viljakatel, niisketel, hästi dreenitud pinnastel.

Arvestades toodud põhimõtteid, võib autori arvates uute katsekultuuride rajamiseks soovitada järgmisi näidis-kultuuritüüpe. 
Ohele hektarile istutada pähklipuid 1160 tükki ja harilikke tammi 2320 tükki. Pähklipuude ja tammede ridade vahekaugus $2,4 \mathrm{~m}$ ning kaugus puude vahel ridades nii pähklipuude kui ka tammede puhul 1,2 m. Pähklipuude ja tammede ridade vahele istutada põõsasliike, nagu kuslapuu, leedripuu, sarapuu jt., arvult 3500 tükki. Seega tuleks

a

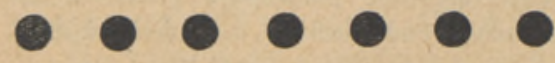
$++++++$

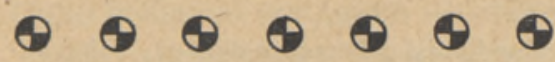
$++++++$

$\theta \oplus \theta \oplus \theta$ $t^{+}+0^{+}+0_{0}^{+}$
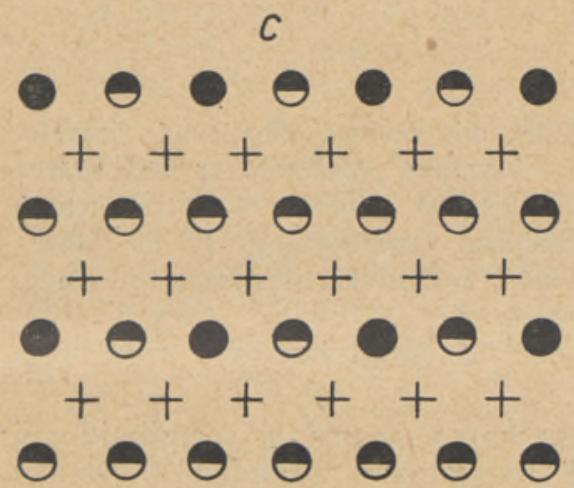

$b$

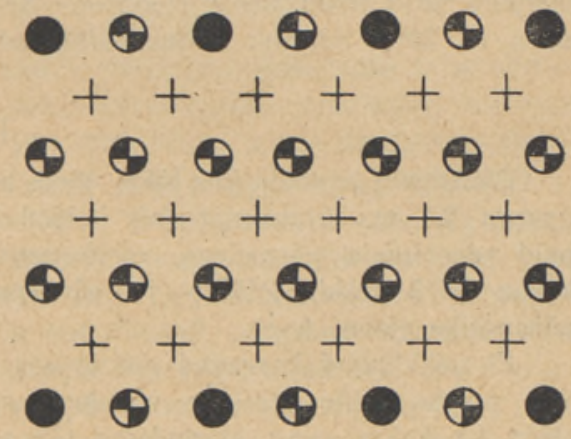

d

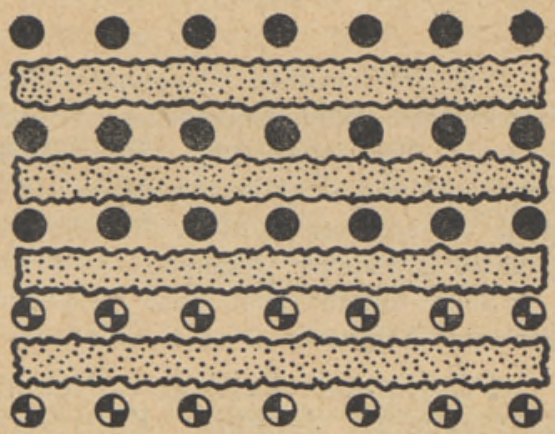

Märkide seletus:

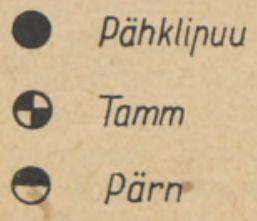

+ Döösosliigid

Lehtpuu noorendik

Joon. 4.

puid ja põõsaid kokku ühe hektari kohta 6980 tükki, millest pähklipuid 16\%, tammi $33 \%$ ja pōōsasliike $51 \%$ (joon. $4, a$ ). Tammi võib asendada ka teiste väärislehtpuudega, nagu vaher, künnapuu, jalakas, ameerika saar jt. (kas ühe nimetatud puuliigiga vői nende seguga).

Kui kultiveerimisalal enne kultuuri rajamist esineb juba loodusliku alusmetsa pōōsas- vōi puuliike, nagu sarapuu, toomingas jt., siis tuleb need tingimata säilitada ning täiendada kultiveerimisel põõsasliike ainult vajaduse järgi. Tulevikus kujunevad säärastest kultuuridest pähklipuu ja teiste väärislehtpuu üherindelised segapuistud, mille 
koosseisus on $33 \%$ pähklipuid ja $67 \%$ väärislehtpuid. Sellist tüüpi on soovitav rakendada naadi-sinilille kuni sōnajala kasvukohatüübile.

\title{
II tüüp
}

Muus osas sarnane eelmisega, kuid pähklipuude istutusmaterjali kokkuhoidmiseks kultiveerida pähklipuude ridades pähklipuid vaheldumisi kas tamme või mõne teise väärislehtpuuga (joon. $4, b$ ). Selle variandi puhul istutada pähklipuid 870 ning teisi väärislehtpuid 2610 tükki ühele hektarile. Sel juhul jääb tulevikus pähklipuid puistu koosseisu ka 20\%. Säärast kultuuritüüpi tuleks rakendada naadi-sinilille kasvukohatüübi'e.

\section{III tüüp}

Pähklipuid istutada 870 tükki ühele hektarile vaheldumisi pärnade ridadega, vahekaugusega $2,4 \mathrm{~m}$. Istutusmaterjali kokkuhoidmiseks kultiveerida pähklipuuridades pähklipuid vaheldumisi pärnadega, vahekaugusega $1,2 \mathrm{~m}$. Seega tuleks ühele hektarile pärni kokku 2610 tükki. Pähkli- ja pärnapuude ridade vahele istutada vajaduse korral põõsasliike (joon. $4, c$ ).

Et pähklipuud kasvavad noores eas kiiresti, siis kujuneb tulevikus välja kaherindeline puistu, mille ülarinde moodustavad pähklipuud, arvestusega lōppraides ca 500 tükki ha kohta, ning alarindesse jäävad pärnad.

Kirjeldatud kultuuritüüpi võib rakendada pärna kasvukohatüübile, kus peale pärna sageli esineb sarapuu alusmetsa.

\section{IV tüüp}

Vähemväärtuslikel lehtpuunoorendike kasvualadel, mis sobivad pähklipuude kasvatamiseks, võib lehtpuunoorendike rekonstrueerimiseks kasutada pähklipuid ja teisi väärislehtpuid. Păhklipuud tuleb sisse viia koridoridena. Selleks raiutakse $4 \mathrm{~m}$ vahekaugusega koridorid ning koridoridesse istutatakse pähklipuud vahekaugusega $1,5 \mathrm{~m}$. Pähklipuid on soovitav kultiveerida ribadena, vaheldumisi teiste väärislehtpuude ribadega. Ribasse istutatakse pähklipuud 3-4-realiselt (joon. 4, d).

Seda kultuuritüüpi saab rakendada naadi-sinilille kasvukohatüübile, mille vōsa keskmine kõrgus on $2-4 \mathrm{~m}$.

Pähklipuude kultiveerimisel kasutatakse kas kaheaastasi seemikuid või kolmeaastasi istikuid. Kultiveerimistööd teostatakse kevadel; Kuremaa Metsakooli kogemused on näidanud, et sügisel rajatud kultuurid õnnestuvad vähem.

Pähklipuu dekoratiivse ilu ja väärtusliku puidu pärast tuleks soovitada hallpähklipuu kasvatamist meie metsakultuurides. Hallpähklipuu kultuuride rajamist õigustavad seniste vaatluste tulemused. Eesti NSV Póllumajanduse Ministeeriumi
Kuremaa Metsakool

Saabus toimetusse

22. II 1954

\section{О РАЗВЕДЕНИИ ОРЕХА СЕРОГО (Juglans cinerea L.) В ЭСТОНСКОЙ ССР}

\author{
О. Ю. ХЕННО
}

Резюме

В Эстонской ССР до сих пор было произведено мало опытов для выяснения возможности разведения ореховых. Единственное в своем роде насаждение ореха серого находится в лесхозе Куриста, у лесной школы Куремаа, в обходе Лууа лесничества Каарепере, на площади 0,8 га (кварталы 137 и 139). 
Эта древесна́я порода произрастает здесь на глубокой карбонатной суглинистой и супесчаной почве на западном склоне ложбнны. Қультура ореха серого заложена здесь в 1911 году чистой породой, густотой размещения $2,4 \times 2,4$ м. В качестве посадочного материала были использованы сеянцы, выращенные в питомнике из семян, полученных из Канады.

По данным, полученным на опытной площади, заложенной в 1939 году в кв. 139, основные таксационные элементы насаждения были здесь следующие: возраст 28 лет, средний диаметр на высоте груди 13,1 см, средняя высота $12 \mathrm{~m}$, запас $123,4 \mathrm{~m}^{3}$ на 1 га.

До 1939 года культура ореха развивалась вполне нормально и не страдала от обычных зимних морозов, хотя местоположение для этой породы было выбрано неудачно - открыто доступу северных и восточных ветров.

Но насаждения ореха серого пострадали в суровую зиму 1939/40 г. (самая низкая температура 17 января -44), в результате чего на стволах деревьев появилась односторонняя сухобокость, полосы которой достигали в среднем 1-2 м высоты. Почти все без исключения морозобоины находятся на северо-восточной и восточной стороне ствола, что также указывает на неправильность выбора местоположения. Это подтверждается и тем обстоятельством, что на расстоянии примерно 0,5 км, в парке Куремаской лесной школы, более старые деревья ореха серого, а также ореха Зибольда, растущие под защитой других деревьев, от морозов не пострадали, в настоящее время вполне здоровы и обильно плодоносят. Наиболее поврежденные морозом деревья удалены в порядке санитарной рубки. После рубки на пнях появилась поросль, часть которой удалена, и у каждого пня оставлено только по 1, реже по 2 побега. Так как поросль показала хороший прирост, то в последующие годы на кв. 139 были вырублены почти все поврежденные морозом деревья.

После проведенной в 1953 году рубки ухода состояние насаждения было следующим: общее количество деревьев 867, из них 89 деревьев ореха серого первоначальной посадки и 461 дерево порослевого происхождения. Количество деревьев ореха серого составляло $63 \%$ от общего количества деревьев. Общий запас достигал $110,5 \mathrm{~m}^{3}$, в том числе запас ореха серого - 43,5 $\mathrm{m}^{3}$, или $39 \%$.

При рубке ухода в 1953 году было вырублено $30,5 \%$ первоначального запаса. Замечателен интенсивный рост ореха серого порослевого происхождения - 10-летние деревья имеют среднюю высоту 9 м и средний диаметр 8,6 см. Молодые деревца, развиваясь совместно с подгоняющими породами (ясень, клен, береза, ольха серая и др.) (рис. 2), показали также хорошее формирование ствола (рис. 3 ).

При культивировании ореха серого необходимо исходить из лесорастительных условий, соответствующих этой породе, а также из качества семян. Орехи необходимо собирать с деревьев, растущих группами, где обеспечено взаимное перекрестное опыление.

В условиях Әстонской ССР лучшим методом культивирования ореха является посадка сеянцами или саженцами. Особое внимание следует уделять соответствующему хранению семян и их стратификации. Стратифицированные орехи следует высевать в питомнике в середине мая. Всхожесть орехов в питомниках при нормальных условиях в среднем $60-70 \%$. Для получения доброкачественных саженцев необходимо перешколивать однолетние сеянцы, притом обязательно весной, так как проведение этой работы осенью, по данным лесной школы, не дало желательных результатов.

При закладке ореха необходимо обратить особое внимание на правильный выбор местопроизрастания и метода закладки культуры. Пригодными для ореха серого считаются участки с глубокими, плодородными, влаж- 
ными почвами, но с подвижной грунтовой водой. Такими участками являются прибрежные полосы рек и осушительных каналов на склонах груд, защищенных от ветров и пригодных также для разведения других ценных пород (дуб, клен и др.).

Oрех рекомендуется закладывать в смешанном составе, так как для лучшего формирования ствола необходимы подгоняющие породы, каковыми являются в молодом возрасте ореха кустарниковые породы и позже - дуб, клен, вяз, ильм, ясень американский, липа и временно ольха серая, осина и береза.

В молодом возрасте ореховые теневыносливы и не страдают от угнетения сопутствующих деревьев. В старшем возрасте орех серый является светолюбивой породой, поэтому для него необходимо создать отдельный верхний полог. На основании этого выращивание ореха серого в смеси с местными обыкновенными породами, как, например, с березой и осиной, может быть допущено лишь при посадке его большими группами, так как прирост в высоту сопутствующих пород значительно превышает прирост ореховых.

В условиях Эстонской ССР орех серый на плодородных, влажных и хорошо дренированных почвах является ценной породой для реконструкции малоценных молодняков.

Учитывая все вышесказанное, можно рекомендовать следующие типы закладки новых культур ореха серого (рис. $4, a, b, c, d)$.

I т и п. На 1 га площади сажают 1160 деревьев ореха серого, 2320 деревьев дуба или других ценных пород и 3500 шт. кустарниковых пород; в случае, если кустарниковые породы уже имеются на месте, при надобности их пополняют. В будущем из таких культур образуются одноярусные смешанные насаждения, в состав которых войдут орех серый (33\%) и другие ценные породы $(67 \%)$ (рис. $4, a)$.

II т и п в общем сходен с предыдущим, но для экономии посадочного материала ореха серого его сажают в рядах попеременно с дубом или другими ценными породами (рис. $4, b)$. В этом случае расход саженцев ореха серого - 870 шт. и других ценных пород - 2610 шт. на 1 га.

III т и п сходен с предыдущим, причем орех серый сажают вместе с липой (рис. $4, c)$. В будущем из таких культур образуются двухярусные насаждения: при окончательной рубке в верхнем ярусе останется приблизительно 500 деревьев ореха серого, а в нижнем ярусе - липа.

IV т и п. Орех серый применяется для реконструкции малоценных лиственных молодняков. Посадку производят коридорным способом, причем рекомендуется сажать орех серый полосами, попеременно с полосами из других ценных пород. На одной полосе высаживают не менее $3-4$ рядов ореха серого (рис. $4, d$ ).

Закладку ореха серого производят двухлетними сеянцами и трехлетними саженцами, притом обязательно весной, так как осенние посадки, как показывают опыты Куремаской лесной школы, не дают желательных результатов.

Куремаская лесная икола Министерства сельского хозяйства ЭССР 